\title{
The RPE Cell and the Immune System
}

\author{
Barbara Detrick and John J. Hooks
}

\section{Introduction}

In addition to its indispensable role in the visual system, immunologically the RPE cell is a pivotal retinal cell that participates in the ocular immunity. Recent discoveries have highlighted the importance of this cell in regulating health and disease and our understanding about immunity in the ocular microenvironment has grown exponentially in the last several years. The RPE cell orchestrates both innate and adaptive immunity and contains a plethora of factors to regulate the immune response [1]. Compelling evidence now suggests that immune activation of the RPE cell may have far reaching effects in retinal infections, autoimmunity and retinal degenerations, i.e. age related macular degeneration (AMD) and diabetic retinopathy. As we review the varied ways in which the RPE cell influences ocular immunity, we will highlight possible mechanisms to explain how these responses impact vision.

\section{B. Detrick $(\bowtie)$}

Department of Pathology and Medicine, School of Medicine, The Johns Hopkins University, Baltimore, MD, USA

e-mail: bdetrick@jhmi.edu

\section{J. J. Hooks}

Laboratory of Immunology, National Eye Institute, National Institutes of Health, Bethesda, MD, USA

\section{RPE Cell: Role in Ocular Innate Immunity}

The immune system is composed of two major recognition systems: innate immunity and adaptive immunity. Innate immunity is considered the immediate immune response to an insult or pathogen, is nonspecific and does not confer long-lasting protective immunity. Nevertheless, it often determines the fate of the adaptive immune response. Once engaged, innate immunity can activate a series of immune components: such as, microbial sensors (Toll-like receptors (TLRs), NOD-like receptors, NLR, RIG-1 like helicases), certain critical cell types, cytokines, chemokines as well as a group of complement components; all directed to assist the host with eliminating the current insult (Table 6.1).

Over the last several decades, tremendous progress has taken place in the field of immunology. Many of these advances have enhanced our understanding of how the immune response impacts human health and disease and have uncovered novel therapeutic approaches to treat many human disorders [2]. In this chapter, we will not attempt to identify all of the new immunologic developments that have been reported. Rather, we have chosen to highlight a few discoveries that have relevance within the retina that better inform about mechanisms of ocular diseases and potential treatment strategies. Current reviews will be included in areas not covered in detail. 
Table 6.1 RPE cell participation in innate immunity

\begin{tabular}{|c|c|}
\hline $\begin{array}{l}\text { RPE cell } \\
\text { component }\end{array}$ & Immune responses generated \\
\hline \multirow{5}{*}{$\begin{array}{l}\text { Immune sensors } \\
\text { (TLRs, NOD-like } \\
\text { receptors) }\end{array}$} & $\begin{array}{l}\text { - Cytokine/chemokine } \\
\text { production }\end{array}$ \\
\hline & - Pro-inflammatory responses \\
\hline & $\begin{array}{l}\text { - TLR3 leads to photoreceptor } \\
\text { and RPE modulation }\end{array}$ \\
\hline & - VEGF production \\
\hline & - Cell death or protection \\
\hline \multirow[t]{3}{*}{ Cytokines } & $\begin{array}{l}\text { - IL-6, IL-1 } \beta \text {-inflammatory } \\
\text { activity }\end{array}$ \\
\hline & $\begin{aligned}- & \text { IFN- } \beta, \text { IL-11, TGF- } \beta- \\
& \text { immunosuppressive activity }\end{aligned}$ \\
\hline & $\begin{array}{l}\text { - IL-6, MCP-1- } \\
\text { influence angiogenesis }\end{array}$ \\
\hline \multirow[t]{3}{*}{ Chemokines } & $\begin{array}{l}\text { - CXCL9, CXCL10-Attract T } \\
\text { and NK cells }\end{array}$ \\
\hline & - CXCL8-Attracts neutrophils \\
\hline & $\begin{array}{l}\text { - MCP-1-Attracts monocytes, } \\
\text { dendritic cells and memory T } \\
\text { cells }\end{array}$ \\
\hline \multirow[t]{2}{*}{$\begin{array}{l}\text { Growth factor } \\
\text { production }\end{array}$} & $\begin{array}{l}\text { - VEGF-Induces } \\
\text { neovascularization }\end{array}$ \\
\hline & - PDGF \\
\hline \multirow[t]{3}{*}{$\begin{array}{l}\text { Complement } \\
\text { components }\end{array}$} & $\begin{array}{l}\text { - CD46, CD55, CD59- } \\
\text { Downregulates complement } \\
\text { activation }\end{array}$ \\
\hline & $\begin{array}{l}\text { - C3a and C5a receptors- } \\
\text { Induces inflammation }\end{array}$ \\
\hline & $\begin{array}{l}\text { Associated with alterations in } \\
\text { AMD and other dystrophies }\end{array}$ \\
\hline
\end{tabular}

\section{Components of Innate Immunity}

\section{Toll-Like Receptors}

TLRs are a family of evolutionary conserved innate immune recognition molecules that sense molecular patterns associated with microbial pathogens. TLR recognition of these microbial patterns leads to a signal transduction cascade that generates a rapid and robust inflammatory response marked by cellular activation and the production of a variety of cytokines, including pro-inflammatory cytokines, cytokines that promote $\mathrm{T}$ cell differentiation, type 1 interferons and chemokines. Since their discovery in 1980, the TLR molecules have been described in numerous cell types throughout the body [3]. Currently, the human TLR family comprises ten TLRs and each is distinguished by their ligand specificity [3]. Also, each TLR has a unique location and expression pattern within the cell. For example, TLR3, 7 and 9 are located manly within the cellular endosome while the remaining TLRs (TLR2, 4, 5, 6) are found on the cell membrane. Overall, TLRs located on the cell membrane recognize bacterial products (i.e. TLR4 recognizes bacterial lipid A from Gram negative bacteria) while the intracellular TLRs detect viral or bacterial nucleic acids (i.e. TLR3 interacts with dsRNA formed during virus replication).

These sentinel molecules were originally described on the RPE cell well over 10 years ago [4]. It is not surprising that the RPE cell is endowed with many of the TLRs, since it is strategically situated and can provide a rapid defense system for the retina [4]. Analysis of TLR gene expression identified the presence of TLR1 through 7, 9 and 10 on human RPE cells. Interestingly, TLR3, a vital TLR for defense against virus infection, is the most highly expressed TLR on the RPE cell. TLR3 recognizes a dsRNA motif, an intermediate product of virus replication or an analog of dsRNA, polyinosinic:polycytidylic acid (Poly I:C). Analysis of signaling through TLR3 revealed that the RPE cell secreted several pro-inflammatory mediators, including, IL-6, IL-8 (CXCL8), MCP1, ICAM-1, CXCL9, CXCL10 and VEGF [5]. These molecules provide signals for immune and retinal resident cells to activate and initiate inflammatory pathways. An important immunosuppressive cytokine, that is selectively upregulated by TLR3, is IFN- $\beta$. This cytokine and its unique interaction with the RPE cell will be discussed later.

Interest in the retinal TLRs has continued at a rapid pace and recent work has demonstrated a potential involvement of TLRs in a variety of retinal diseases. For example, TLR polymorphisms have been associated with AMD [6, 7]. Investigations exploring the utility of siRNA treatment for AMD, identified that siRNA signaled through TLR3 $[8,9]$. This signaling process results in the inhibition of vascular endothelial growth factor (VEGF) expression. These studies suggest a mechanism by which siRNA molecules can inhibit neovascularization in AMD. Also, the critical importance of the 
TLRs is underscored by recent investigations evaluating deficiencies in TLR. In a mouse model of diabetic retinopathy it was reported that a deficiency in TLR7 inhibits inflammation and this lack of TLR7 results in an attenuation of diabetic retinopathy [10].

Several investigators have identified that activation of TLR3 within RPE cells is associated with RPE cell damage that may contribute to retinal degenerations in AMD and other retinal disorders [11, 12]. Klettner and associates found that TLR3 activation in RPE cells results in cell death partly mediated by JNK [13, 14]. Alternatively, studies have also demonstrated a protective role for TLR3 signaling. Patel and associates have shown that TLR3 signaling through a STAT3 dependent mechanism protects RPE cells from oxidative stress $[15,16]$. Taken together, these studies illustrate the major position of the RPE in innate immunity and stress the plethora of responses TLR signaling affects. Future experiments are needed to better define the role of TLRs in human ocular diseases and to pinpoint additional strategies that limit or boost their function [12].

\section{Cytokines}

Cytokines are potent, low molecular-weight protein cell regulators often produced transiently and locally by many cell types. Following their initial discovery nearly 60 years ago, the cytokine definition has grown to include their multiple effects as pleiotropic proteins whose biological properties support key roles in hematopoiesis, immunity, infectious disease, tumorigenesis, homeostasis, cellular development and growth. Thus, because of their varied participatory roles, we recognize these molecules as powerful agents that control many aspects of health and disease and as potential therapeutic tools for variety of immune based disorders. Immunologically, cytokines have emerged as mediators that bridge innate and adaptive immunity, as molecules that participate in both inflammatory and antiinflammatory activities and as regulators that influence numerous diseases.

The body is filled with cells that produce cytokines and each cell is strategically designed and ready to generate a cytokine signature when needed. Within the retina, the RPE cell serves as a rich source of cytokines. Many of the cytokines produced, such as, IL-6, IL-8, MCP-1, CXCL9 and CXCL10 are pro-inflammatory and will be highlighted here. The immunosuppressive cytokines produced by the RPE cell will be discussed in the immunoregulation section.

In the early and mid 1980s, IL-6 was first described as a lymphocyte stimulating factor that activated $T$ cells and differentiated $B$ cells. Now some 40 years later, we appreciate that IL-6 exerts its effects on a broad variety of responses ranging from acute and chronic inflammation to vascular disease and because of these multiple activities, this cytokine is now considered a primary target for clinical intervention [17].

In the eye, numerous cells generate IL-6. The RPE cell produces high levels of IL-6 in response to several stimuli, such as, infectious agents, other cytokines (IL- $1 \beta$, TNF- $\alpha$ and IFNs) and TLR ligation [18, 19]. As we have witnessed elsewhere in the body, the release of IL- 6 by the RPE cell may be an important component of a chronic as well as acute inflammatory response in the retina. Based on the analysis of systemic diseases several studies have implicated the persistent production of IL6 as a cytokine involved with the onset and development of autoimmunity [20, 21]. In order to better understand pathogenic mechanisms in autoimmune retinopathy (AIR), we evaluated the presence of cytokine markers in AIR patients. Recently, our laboratory identified the increased presence of IL-6 and CXCL9 in AIR patient sera and show that these elevated levels correlate with augmented disease severity. These studies provide evidence that IL- 6 and CXCL9 may participate in AIR pathology [22]. A previous study using flow cytometric immunophenotyping to analyze this same cohort of patients noted that B-lymphocyte anomalies were described in AIR patient plasma compared to normal and uveitic patient samples [23]. Both of these observations hint that the immune response may play a role AIR. Nevertheless, additional investigations are needed to unravel the involvement of the immune response in this 
rare disease with the hope that more definitive guidelines for diagnosis and treatment strategy will be developed.

Chemokines are a superfamily of small diffusible protein molecules $(8-14 \mathrm{kDa})$ secreted by various cell types in response to inflammatory, infectious and autoimmune disease signals [24]. Chemokines participate in inflammation by regulating neutrophil, macrophage and lymphocyte trafficking to the pathologic site. The presence of chemokine expression in the retina has been associated with a number of retinal disorders. Numerous studies have revealed that within the retina, the RPE cell provides high levels of IL-8, MCP-1 and CXCL9 and CXCL10. IL-8, often identified as one of the early inflammatory mediators following injury, is a potent chemoattractant and activator of neutrophils. In addition, IL-8 promotes the migration and proliferation of endothelial cells and possesses strong angiogenic properties within the eye. Another chemokine that directs monocytes, memory $\mathrm{T}$ cells and dendritic cells to an inflammatory site and is associated with neovascularization, is CCL2 (MCP-1). Like IL-8, this chemokine has also been implicated in number of disorders within the retina. Not long ago, Chan and colleagues demonstrated in an animal model that CCL2 was associated with AMD. The authors show that mice deficient in CCL2 develop a retinal disease that mimics human AMD [25].

As a result of extensive work examining the immunoregulatory role of the IFN molecules in the immune response, a group of chemokines was discovered. CXCL9 and CXCL10 are interferon inducible chemokines that interact with their receptor, CXCR3, on the surface of $\mathrm{T}$ cells and NK cells resulting in the migration and activation of these cells into inflamed sites. Following the first description of these two chemokines by Detrick et al., in a degenerative disease, experimental coronavirus retinopathy (ECOR), Nawaz and collaborators also detected both CXCL9 and CXCL10 on retinal endothelial cells in human diabetic retinopathy $[26,27]$. Additional chemokine signaling studies were reported in a rodent model of degeneration by Rutar and associates. These investigators found that CXCL10 was present in this model system and was responsible for the chemokine mediated inflammation observed [28, 29].

Chronic inflammation and exaggerated VEGF production are important hallmarks of choroidal neovascularization in AMD and other vitreoretinal disorders. Moreover, the RPE is a key pathologic site in this disease. Reports from several investigators have shown in vitro that stimulation of RPE cells with cytokines, such as, IL- $1 \beta$, TNF- $\alpha$ and IFN- $\gamma$ results in the production of high levels of VEGF [30, 31]. This example emphasizes the potent influence of immune activated RPE cells and the detrimental consequence of this upregulation of inflammatory cytokines. Based on such findings, strategies to block VEGF production have been developed and anti-VEGF is now considered standard care for AMD. For a more detailed description of VEGF treatment and AMD, we refer the reader to [32].

This is an exciting time in cytokine biology. As a result of these new discoveries, it is anticipated that continued research will further our understanding and offer new options for therapeutic interventions.

\section{Complement}

The complement system, a complex and sophisticated network of various proteins, regulators and receptors, is an integral component of innate and adaptive immunity. Over the years there has been a rebirth of interest related to the complement system. The complement system in the immune privileged-eye plays a critical role in retinal hemostasis by providing the retina neuroprotection. This dynamic proteolytic cascade is tightly regulated and constantly monitors inflammation via its complement regulatory proteins while continuing to eliminate invading pathogens [32].

The RPE cell manufactures and possess on its cell surface many of the complement components. For example, both $\mathrm{C} 3 \mathrm{a}$ and $\mathrm{C} 5 \mathrm{a}$ receptors are expressed on the RPE membrane. When C5a interacts with the RPE C5a receptor, TLR4 is activated to produce pro-inflammatory cytokines, such as IL-1 $\beta$, IL-6, IL-8, MCP-1 and GM-CSF $[33,34]$. In this way the complement system drives inflammation in the retina. 
Alternatively, as mentioned above, the complement system also has designed ways to downregulate its activity through three major membrane complement regulatory proteins, CD46, CD55 and CD59. CD46 and CD55 act early in the complement cascade to inhibit $\mathrm{C} 3$ and $\mathrm{C} 5$ convertase. CD59 acts later in complement pathway to block C9 and the membrane attack complex, MAC. All three of these regulatory proteins are found on the RPE cell [35]. Pro-inflammatory cytokines, for example, IL1 $\beta$ and TNF- $\alpha$, amplify the expression of CD46 and CD59 and thus may provide protection to the RPE cell from complementmediated cytolysis. Thus, the RPE cell is responsible for maintaining a delicate balance between initiating inflammation and suppressing complement-medicated inflammation.

Based on a number of eloquent studies, there is significant evidence that altered regulation of the complement system may be associated with AMD and Stargardt's disease [36, 37]. These exciting reports identified a strong genetic component that links complement regulatory protein polymorphisms and MAC formation. During the course of AMD, both MAC and C5a have been described to accumulate in drusen and in RPE $[34,35]$. These studies add to our current understanding that chronic inflammation and dysregulation of complement regulatory proteins promote inflammation and thus contribute to a retinal degenerative process. Another RPE associated factor, Apolipoprotein E (APoE) has been shown to participate in lipid metabolism and neurodegeneration. Complement activation induces ApoE accumulation in RPE cell and ApoE is commonly detected in the RPE and drusen component in AMD [38].

\section{RRPE Cell: A Sentinel Cell and Innate Immunity}

Since the RPE cell is endowed with many of the components of the innate immune response, it can serve as a first responder to infectious insults. When one reviews the literature on examples of retinal infections, it becomes apparent that the varied infectious agents used the RPE cell as a refuge. This is true for systemic cytomegalovirus infection, cytomegalovirus retinopathy, corona- virus in experimental coronavirus retinopathy (ECOR), HIV in AIDS, and ocular infections associated with mycobacterium tuberculi and Toxoplasma gondii [39-43]. As discussed above, the RPE cell provides the first line of defense and is posed to eliminate the pathogen with its multiple TLR molecules, interactions with immune cells and production of soluble mediators [5]. However, for many infectious agents, activation of the adaptive immune response is required.

\section{RPE Cell and Microglia Interactions}

Microglia are resident macrophage cells in the brain and retina. These cells participate in a number of immunologic activities, such as, the production of both pro- and anti-inflammatory cytokines and molecules. Microglia cells are therefore important immunoregulatory cells that are capable of rapidly responding to a variety of warning signals. Numerous studies have identified that microglia activation in the brain is associated with a variety of neurodegenerative and neuroinflammatory diseases. Not surprisingly, these cells in the retina, are also activated in retinal degenerative and inflammatory conditions.

Thus, both the RPE cell and the retinal microglia cells are capable of participating in inflammatory and degenerative processes. Within the retina, studies have shown that the RPE cells and the microglia may interact, and cross talk with one another, especially through the production of cytokines [15]. As we have seen, the RPE cells are activated by TLR3 stimulation and produce a variety of potent cytokines [5]. Klettner and associates showed that supernatant fluids from TLR3 activated RPE cells can up-regulate microglia cells to produce IL-1 $\beta$, IL-6 and Cox-2. These studies provide evidence that RPE cells may act as an inflammatory signal for microglia cells.

These initial studies have been expanded to investigate the cross-talk between RPE and microglia. Jo and associated demonstrated that interaction between these cells determines the integrity of the outer blood-retinal barrier in murine diabetic retinopathy [44]. This interaction was mediated by the presence of IL- 6 and the production of TNF- $\alpha$ by the microglia cells. In a rat model of photo oxidative damage, which has 
similarities with AMD, IL-1 $\beta$ produced by microglia was associated with increased expression of the chemokines, CCL2, CXCL1 and CXCL10 in the RPE cell. The authors stress the potential importance of these chemokines in AMD. Using the human ARPE-19 in vitro, it was demonstrated that activation of microglia cells triggered inflammasome activation in RPE cells with resultant lysosomal destabilization [45]. In summary, these exciting studies substantiate significant immunologic collaboration between the RPE cell and the microglia cell within the retina. Moreover, these studies highlight the need for continued studies exploring the relationship between these cells and their potential role in a variety of retinal disorders.

\section{RPE Cell Participation in Immunoregulation}

Inflammation in the retina is a critical response of the host to retinal insults and is outlined in Fig. 6.1. Regulation of the immune system is clearly an important area of research. In fact, studies identifying how tumor cells escape immune destruction by the PD-L1 pathway has led to exciting novel cancer treatment strategies. The concept of regulatory mechanisms in the ocular microenvironment that restrain immune-mediated inflammation is not new. Over 70 years ago, Sir Peter Medawar identified the concept of immune privilege in the brain, eye and the pregnant uterus [46]. Today, we know that immune privilege extends to the anterior chamber as well as the retina where an array of regulatory mechanisms act in concert to prevent immunologic inflammation and maintain tissue integrity [47, 48]. Some of these mechanisms include the presence of a blood-retinal barrier, a lack of lymphatic drainage, the presence of immunosuppressive cytokines and regulatory $\mathrm{T}$ cells. Controlling unnecessary inflammation is not an immunologically inert activity but rather a very active process that allows the eye to escape the damage associated with a full blown inflammatory response. Today, we recognize that the RPE cell is a major player in this dynamic regulatory pathway.
The eye has evolved suppressive mechanisms to down-regulate the immuneresponse and one way in which this RPE cell participates to control unwanted activation is by producing cytokines. An outline of the immune-protective role of the RPE cell is seen in Figs. 6.2, 6.3, and 6.4. The RPE cell releases three suppressive factors including TGF- $\beta$, IL-11 and IFN- $\beta$. One of these molecules highly expressed in the RPE cell is IFN- $\beta[5,6]$. It is well known that the IFNs are involved in numerous immune reactions and induction of type 1 IFN gene expression is an essential part of innate immunity [4]. Since the RPE cell continuously expresses high levels of IFN$\beta$ through IRF-7 up-regulation, our laboratory explored ways in which this molecule may function in the retinal microenvironment (Fig. 6.2). In vitro experiments and in vivo studies show that IFN- $\beta$ acts as an immunosuppressive cytokine to block immune reactivity and thus protect the retinal tissue from excessive damage and visual loss [6]. IFN- $\beta$ provides this protection in two ways. IFN- $\beta$ can down-regulate CXCL9 and the adhesion molecule, ICAM-1. The net effect of this activity would be a "tightening" of the blood retinal barrier and decreased ocular inflammation [49].

IL-11 is another interesting member of the IL6 family of cytokines and is produced in elevated levels by the RPE cell [50]. This pleiotropic cytokine has anti-inflammatory and cytoprotective actions [51]. Under normal conditions the RPE cell does not produce IL-11, however, following treatment with TGF- $\beta$, IL- $1 \beta$ or TNF- $\alpha$, an upregulation of gene expression and protein production of IL-11 is observed (Fig. 6.3). Therefore, during inflammation, IL-11 is produced by the RPE cell and then participates by limiting inflammation and providing cytoprotection to the RPE and other retinal cells [52].

TGF- $\beta$ is a potent multifunctional cytokine that has been shown to provide immunosuppressive actions in the eye [53]. These studies have shown that TGF- $\beta$ down-regulates APC function and inhibits several $\mathrm{T}$ cell functions contributing to ocular immune privilege. Several investigators have also shown that the presence of TGF- $\beta$ is associated with retinal disorders, such as retinal detachments, proliferative vitreoretinopathy and choroidal neovascularization. As noted above, 
Fig. 6.1 Inflammation within the retina. IFN- $\gamma$ generated by activated $\mathrm{T}$ cells induces RPE cells to express MHC class I and II molecules and to produce proinflammatory cytokines such as IL-6, CXCL8 (attract neutrophils), CXCL9, CXCL10, CXCL11 (attract T cells). CXCL9 is also produced by retinal vessel endothelial cells

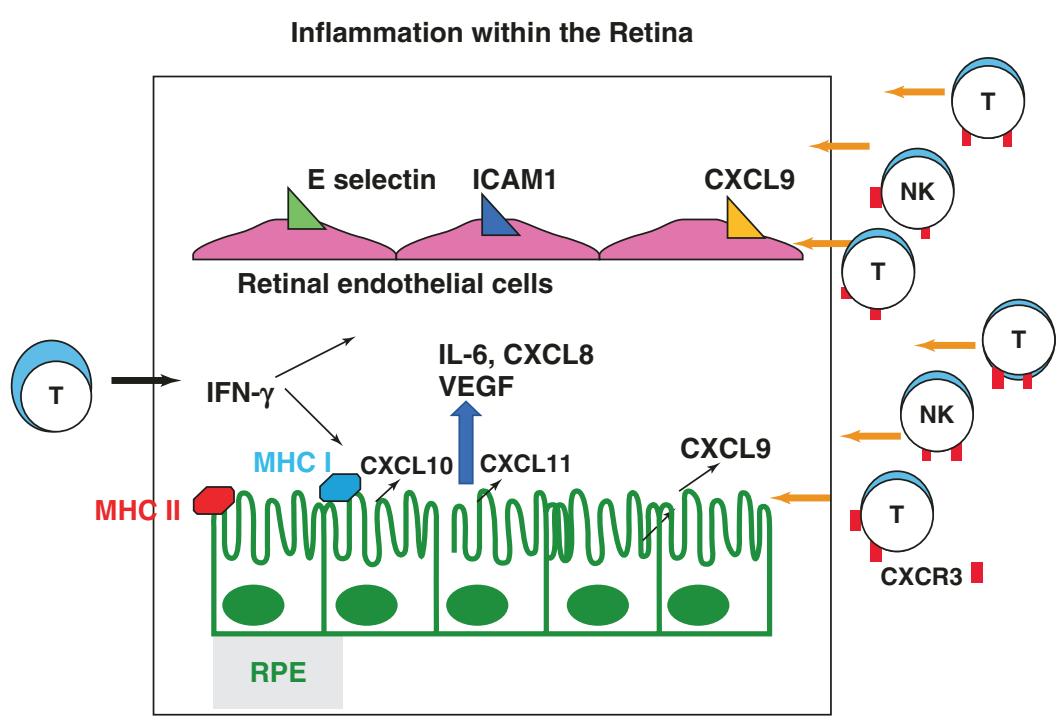

IFN- $\gamma$ induced chemokines (CXCL9,10,11) attract T \& NK cells to site of inflammation

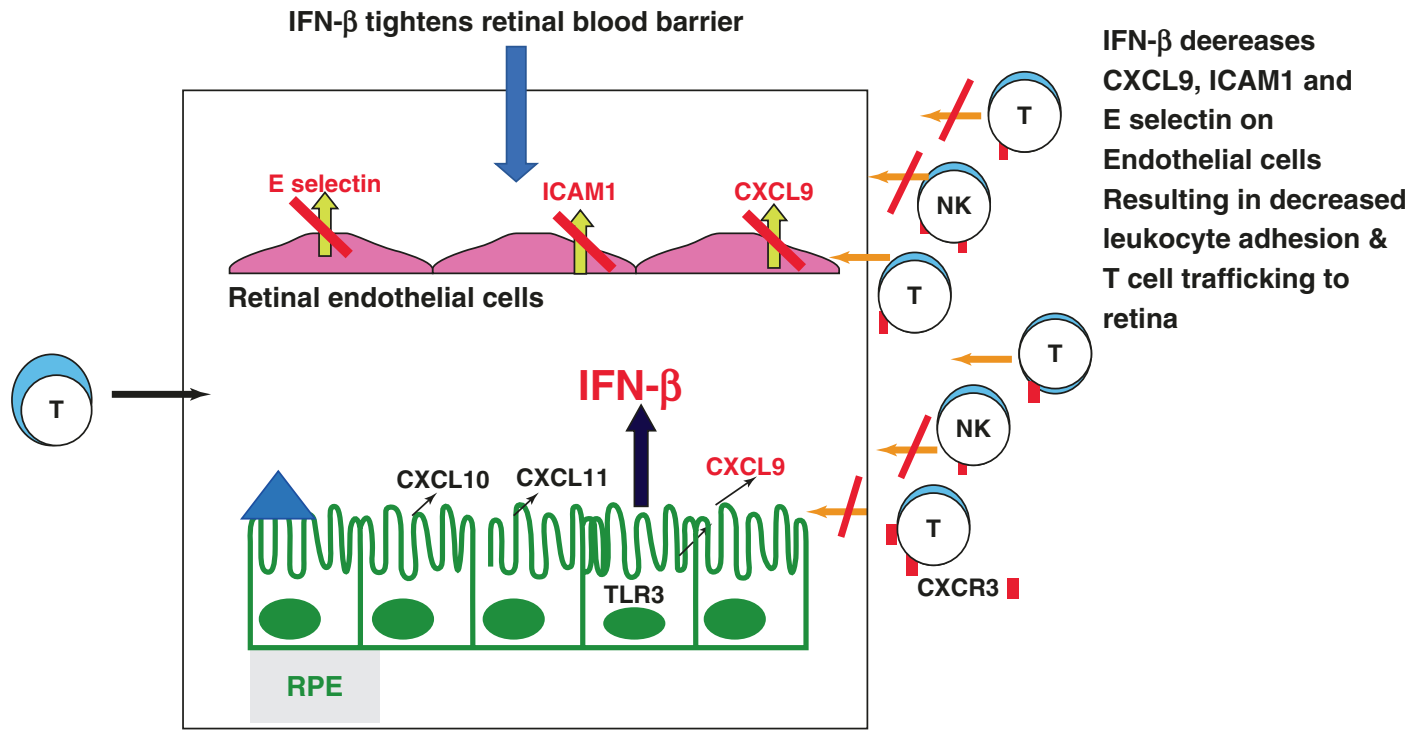

IFN- $\beta$ inhibits CXCL9 expression and decreases T \& NK cell migration

Fig. 6.2 IFN- $\beta$ inhibits CXCL9 expression and decreases $\mathrm{T}$ and Natural Killer (NK) cell migration. High levels of IFN- $\beta$ are produced by the RPE cells through the activation of TLR3 within the RPE cell. IFN- $\beta$ decreases

the RPE cell is a major source of TGF- $\beta$. Moreover, TGF- $\beta$ can act upon RPE cell causing the release of VEGF, PDGF and hemooxygenase $[20,54,55]$.
CXCL9, ICAM-1 and E selectin on endothelial cells. This results in a dramatic tightening of the retinal-blood barrier. This also results in decreased leukocyte adhesion and $\mathrm{T}$ cell trafficking into the retina

The manner by which RPE cellular receptor for complement and PD-L1 regulate the immune response have been described and are outlined in Fig. 6.4. 
Fig. 6.3 TGF- $\beta$ and

IL-11 support Treg formation and decreases activated $\mathrm{T}$ cell migration. When activated, the RPE cell produces two additional anti-inflammatory cytokines, TGF- $\beta$ and IL-11. TGF- $\beta$ stimulate CD4+ T cells to differentiate into Tregs. These cells suppress effector T cell activation and proliferation. IL-11 provides protection of Tregs

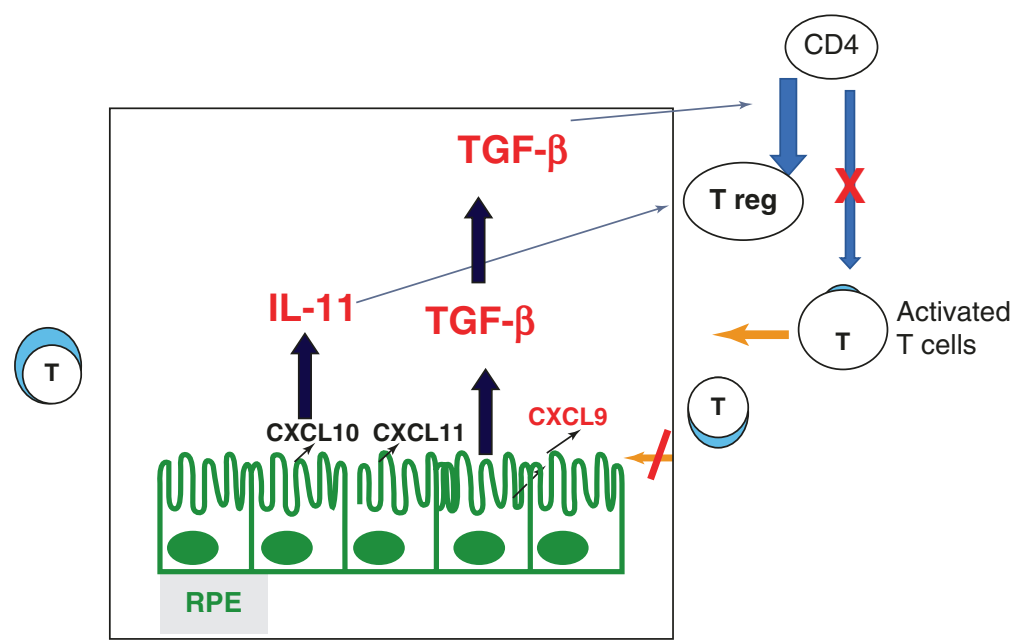

TGF- $\beta$ and IL-11 support Treg formation and decreases activated $T$ cell migration

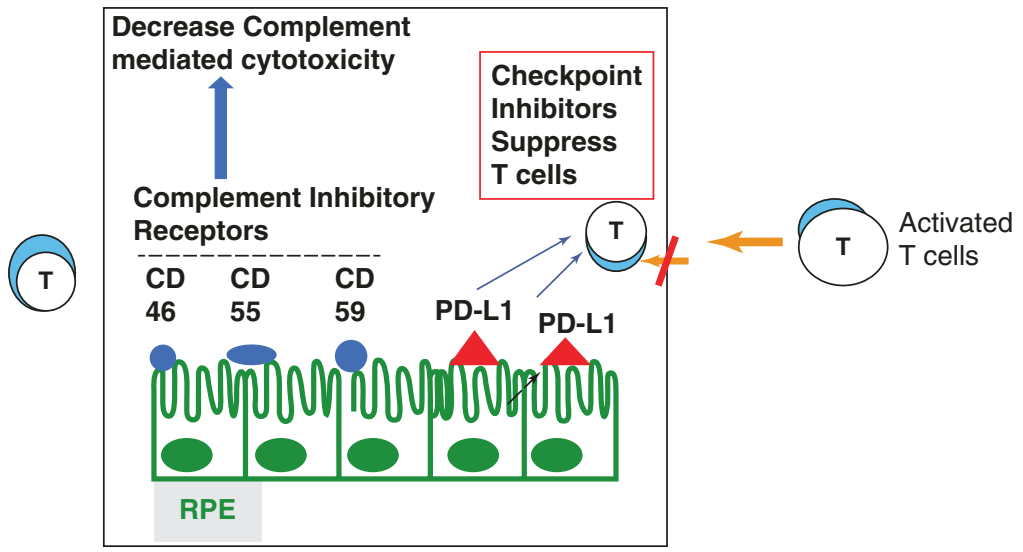

RPE cellular receptors down-regulate T cells and Complement

Fig. 6.4 RPE cellular receptors down-regulate $\mathrm{T}$ cells and Complement. Activated RPE cells express three complement inhibitory receptors. CD46 is a complement regulatory protein that inactivates $\mathrm{C} 3 \mathrm{~b}$ and $\mathrm{C} 4 \mathrm{~b}$. CD55 is a complement decay accelerating factor that indirectly

\section{RPE Cell: Role in Ocular Adaptive Immunity}

Unlike the innate immune response, the adaptive response is highly specific, has immunologic memory, and can respond rapidly and vigorously to a second antigen exposure. The adaptive immune response involves antibody-mediated and cell-mediated immune responses (Table 6.2). Antigen processing and presentation represent blocks MAC formation. CD59 directly blocks MAC formation. Activated RPE cells also express the immune checkpoint inhibitor, PD-L1. Interaction of T cells with this receptor on the RPE cell results in suppression of $\mathrm{T}$ cell activity

the hallmark of the adaptive immune response. An overview of all the components and their interactions during the adaptive immune response is not possible here however, early experiments establishing the RPE as an APC will be briefly mentioned. We direct the reader to the following review, [56].

Major Histocompatibility Complex, MHC, class I and II molecules, which serve as the recognition system capable of distinguishing self 
Table 6.2 RPE cell participation in adaptive immunity

\begin{tabular}{|c|c|}
\hline RPE cell component & Immune responses generated \\
\hline \multirow[t]{3}{*}{ MHC class I } & $\begin{array}{l}-\quad \begin{array}{l}\text { Role in antigen } \\
\text { presentation }\end{array} \\
\end{array}$ \\
\hline & - Modulated by IFNs \\
\hline & $\begin{array}{l}\text { - Participation in } \mathrm{NK} \text { and } \mathrm{T} \\
\text { cell killing }\end{array}$ \\
\hline \multirow{2}{*}{$\begin{array}{l}\text { MHC class II and } \\
\text { costimulatory } \\
\text { molecules (CD80, } \\
\text { CD86) }\end{array}$} & $\begin{array}{l}- \\
\text { Role in antigen } \\
\text { presentation }\end{array}$ \\
\hline & - Modulated by IFN- $\gamma$ \\
\hline Cytokines & $-\quad$ See Table 6.1 \\
\hline $\begin{array}{l}\text { RPE cytokine } \\
\text { receptors }\end{array}$ & $\begin{array}{l}\text { - } \text { Stimulate RPE pro- } \\
\text { inflammatory and } \\
\text { immunoregulatory } \\
\text { cytokines as well as VEGF }\end{array}$ \\
\hline Complement & $-\quad$ See Table 6.1 \\
\hline \multirow{2}{*}{$\begin{array}{l}\text { PD-L1 (programed } \\
\text { death ligand) }\end{array}$} & - Tolerance \\
\hline & - Regulation of T cells \\
\hline
\end{tabular}

from non-self, bind peptide antigens, present them to appropriate $\mathrm{T}$ cells and initiate the first step in antigen recognition. Cells armed with these molecules are capable of becoming antigen presenting cells, APC. Resident APCs can be found in various areas throughout the body, including the retina. Depending on the cell type, these molecules may require activation by IFN- $\gamma$. Both T cells and NK cells can serve as the source of INF- $\gamma$.

Since antigen presentation is the central component of adaptive immunity, our laboratories explored the expression and function of MHC molecules within the retina. When one evaluates the normal retina, MHC class I and II molecules are not expressed. We noted that when retinal tissue obtained from patients with uveitis, retinitis pigmentosa or Sympathic Ophthalmia were evaluated, the RPE cell expressed MHC class I and II molecules and the infiltrating $\mathrm{T}$ cells contained IL-2 and IFN- $\gamma$ [57-59]. Next, our in vitro studies demonstrated that IFN- $\gamma$ treatment up-regulated both class I and class II molecules on normal RPE cells and hence equipped the cell to participate as a resident APC in the retina $[60,61]$. In a series of in vitro studies we demonstrated that both retinal and non-retinal (BCG) antigens can be pro- cessed and presented by the activated RPE cell [60]. These finding were an essential first step underscoring the important role of the RPE cell in inflammatory, infectious and degenerative disorders. In order to further evaluate the RPE cells in vivo, we explored two animal models systems that are described below.

Animal models have been invaluable to assist in uncovering fundamental mechanisms of disease pathogenesis. One of the first animal models to explore retinal inflammation was experimental autoimmune uveitis, EAU, which is a T cellmediated disease that mimics human uveitis [62]. Using this model system, our laboratory tracked the expression of the MHC class II molecules on RPE cells and recorded the entry of inflammatory cells into the retina [63]. Moreover, following the administration of anti-MHC class II antibody prior to EAU induction, we observed that this treatment limited the expression of MHC class II molecules on RPE cells, reduced the severity of disease and significantly delayed the onset of EAU. Collectively, these studies helped to establish the critical role of the RPE cells in ocular autoimmunity and inflammation.

Another animal model system used to clarify basic mechanisms involved in retinal degenerations was experimental coronavirus retinopathy (ECOR) [1]. This is the first retinal model to demonstrate a virus-induced degeneration, viral persistence, a genetic predisposition to virusinduced tissue damage and a virus triggered autoimmune response. ECOR is a retinal degenerative disease that is composed of three basic components; a virus component, a genetic component and an immunologic component [64-66]. Our early studies showed that inoculation of the neurotrophic JHM strain of mouse hepatitis virus (MHV) into the vitreous or anterior chamber of $\mathrm{BALB} / \mathrm{c}$ mice resulted in two distinct patterns of retinal pathology. The early phase of the disease, day $1-8$, was characterized by retinal vasculitis and perivasculitis. The late phase of the disease, after day 10 , was characterized by retinal degenerative changes. The retinal layers revealed disorganization with large areas of outer and inner segment loss. In addition, the RPE cells were morphologically abnormal with foci of RPE cell 
swelling, proliferation and cell atrophy [67, 68]. During this infection, we also noted that the RPE cell was the first cell infected by the virus $[64,65$, 69, 70]. This was not unexpected since the RPE cell serves as an excellent reservoir for numerous pathogens. Analysis of retinal gene expression and protein expression identified the early upregulation of cytokines and chemokines, including, IL-6, TNF- $\alpha$, IFNs, CXCL9, CXCL10 and ICAM-1 [26, 71]. The presence of IFN- $\gamma$ was also detected in the serum and served as the rational for the enhanced expression of MHC class I and II molecules on the RPE cell.

The genetic constitution of the host can be a critical factor in determining the outcome of a viral infection and this was also observed in ECOR [72]. The susceptible strain of mice, $\mathrm{BALB} / \mathrm{c}$, were not the only rodent strain examined. CD-1 mice were extensively studied after coronavirus infection. During the early phase of the disease (day 1-8) both strains of mice showed that the virus infected and replicated within the retina and this was associated with a typical retinal vasculitis. However, on day 10-140, only the $\mathrm{BALB} / \mathrm{c}$ mice experienced the late phase of the disease marked by retinal degeneration. In contrast, in the resistant strain, CD-1 mice, the retina reverted to a normal architecture. We have identified two key differences between the mouse strains that contributed to this retinal degeneration. First, a distinct difference in the intensity of the innate immune response was observed in these mice that developed a retinopathy compared to the mice without late retinal disease. At day 2 and 3 the BALB/c mice had extremely high levels of IFN- $\gamma$, CXCL9 and CXCL10 which was measured by retinal gene expression. These same elevated levels of cytokines were found in the serum [26]. When CXCL9 and CXCL10 interact with its receptor, CXCR3 on $\mathrm{T}$ cells and NK cells, immune cells migrate to specific targets, in this case to the retina. The second distinct difference was the observation that the retinal degenerative process in $\mathrm{BALB} / \mathrm{c}$ mice was associated with the presence of antiretinal autoantibodies. These antibodies were directed against the neural retina and the RPE cell. In contrast, these autoantibodies were not detected in the sera from normal or mock injected BALB/c mice. Likewise, none of the CD-1 mice developed antiretinal antibodies [66]. These mice also produced significantly lower levels of CXCL9 and CXCL10. Therefore, the mice that failed to develop antiretinal antibodies also failed to develop a retinal degeneration. These findings suggest a role for autoimmunity in the pathogenesis of ECOR and illustrate how a robust innate immune response may contribute to a heightened adaptive immune response that leads to a retinal degeneration. This model recapitulates key elements of human retinal degenerative diseases and serves as a template for exploring basic mechanisms of this degenerative process.

\section{Immunologic Tools That Translate into RPE Discoveries}

Development of new powerful technologies to support translational studies in human immunology have led to significant findings in basic and clinical immunology as well as in visual science. We initially investigated the RPE cell by developing monoclonal antibodies to identify epitopes that were unique to the RPE cell [73]. One evolutionally conserved epitope that we identified that was specific only to RPE cells was termed, RPE65 [73, 74]. This molecule has subsequently been the subject of active genetic research. Mutations in the RPE65 gene have been identified in Leber's Congenital Amaurosis. Recently, RPE65 adenoviral vector expressing RPE65 cDNA was used successfully in 12 pediatric patients with this disease [75, 76].

\section{Future Directions and Clinical Applications}

In summary, the RPE cell plays a pivotal role in retina immunity. The RPE cell orchestrates both innate and adaptive immunity and possesses molecules that can limit these responses. The regulation of immunity and hemostasis within the retina through cytokine production, TLR activation, complement regulators and APC properties are all 
key elements in the RPE cell's inventory. Continuing investigations of these immune related components, their complex regulatory networks and their various antagonists will allow even more discoveries and provide additional clues to inform about mechanisms that can lead to future treatments for many human retinal diseases.

\section{References}

1. Detrick B, Hooks JJ. Immune regulation in the retina. Immunol Res [Internet]. 2010;47(1-3):153-61. https://doi.org/10.1007/s12026-009-8146-1. https:// www.ncbi.nlm.nih.gov/pubmed/20082152.

2. Detrick B, Schmitz JL, Hamilton RG. Manual of molecular and clinical laboratory immunology. 8th ed. Washington, DC: ASM Press; 2016.

3. Hunter CA, Jones SA. IL-6 as a keystone cytokine in health and disease. Nat Immunol [Internet]. 2015;16(5):448-57. https://doi.org/10.1038/ni.3153. http://www.nature.com/ni/journal/v16/n5/abs/ ni.3153.html?foxtrotcallback=true.

4. Sabroe I, Parker LC, Dower SK, Whyte MK. The role of TLR activation in inflammation. J Pathol [Internet]. 2008;214(2):126-35. https://www.ncbi.nlm.nih.gov/ pubmed/18161748.

5. Kumar MV, Nagineni CN, Chin MS, Hooks JJ, Detrick B. Innate immunity in the retina: toll-like receptor (TLR) signaling in human retinal pigment epithelial cells. J Neuroimmunol [Internet]. 2004;153(1-2):715. https://www.ncbi.nlm.nih.gov/pubmed/15265658.

6. Hooks JJ, Nagineni CN, Hooper LC, Hayashi K, Detrick B. IFN-beta provides immuno-protection in the retina by inhibiting ICAM-1 and CXCL9 in retinal pigment epithelial cells. J Immunol [Internet]. 2008;180(6):3789-96. https://www.ncbi.nlm.nih.gov/ pubmed/18322185.

7. Edwards AO, Chen D, Fridley BL, James KM, Wu Y, Abercasis G, et al. Toll-like receptor polymorphisms and age-related macular degeneration. Invest Ophthalmol Vis Sci [Internet]. 2008;49(4):1652-9. https://doi.org/10.1167/iovs.07-1378. https://www. ncbi.nlm.nih.gov/pubmed/18385087.

8. Cho Y, Wang JJ, Chew EY, Ferris FL, Mitchell P, Chan CC, Tuo J. Toll-like receptor polymorphisms and age-related macular degeneration: replication in three case-control samples. Invest Ophthalmol Vis Sci [Internet]. 2009;50(12):5614-8. https://doi. org/10.1167/iovs.09-3688. https://www.ncbi.nlm.nih. gov/pubmed/19628747.

9. Kleinman ME, Yamaada K, Takeda A, Chandrasekaran V, Nozaki M, Baffi JZ, et al. Sequence- and targetindependent angiogenesis suppression by siRNA via TLR3. Nature [Internet]. 2008;452(7187):591-7. https://doi.org/10.1038/nature06765. https://www. ncbi.nlm.nih.gov/pubmed/18368052.
10. Kleinman ME, Ambati J. A window to innate neuroimmunity: toll-like receptor-mediated cell responses in the retina. Adv Exp Med Biol. 2012;723:3-9. https://doi.org/10.1007/978-1-4614-0631-0_1.

11. Liao YR, Li ZJ, Zeng P, Lan YQ. TLR7 deficiency contributes to attenuated diabetic retinopathy via inhibition of inflammatory response. Biochem Biophys Res Commun [Internet]. 2017;493:1136-42. https:// doi.org/10.1016/j.bbrc.2017.08.085. pii: S0006291X(17): 1644-3. https://www.ncbi.nlm.nih.gov/ pubmed/28843858.

12. Yang Z, Stratton C, Francis PJ, Kleinman ME, Tan PL, Gibbs D, et al. Toll-like receptor 3 and geographic atrophy in age-related macular degeneration. New Engl J Med [Internet]. 2008;359(14):1456-63. https:// doi.org/10.1056/NEJMoa0802437. https://www.ncbi. nlm.nih.gov/pubmed/18753640.

13. Wörnle M, Merkle M, Wolf A, Ribeiro A, Himmelein $\mathrm{S}$, Kemt M, et al. Inhibition of TLR3-mediated proinflammatory effects by Alkylphosphocholines in human retinal pigment epithelial cells. Invest Ophthalmol Vis Sci [Internet]. 2011;52(9):6536-44. https://doi. org/10.1167/iovs.10-6993. https://www.ncbi.nlm.nih. gov/pubmed?holding=jhumlib_fft_ndi\&otool=jhumli b\&term=IOVS+2011+52\%3A6536-6544.

14. Klettner A, Koinzer S, Meyer T, Roider J. Toll-like receptor 3 activation in retinal pigment epithelium cells-mitogen-activated protein kinase pathways of cell death and vascular endothelial growth factor secretion. Acta Ophthalmol [Internet]. 2013;91(3):e211-8. https://doi.org/10.1111/aos.12031. https://www.ncbi. nlm.nih.gov/pubmed/23387336.

15. Klettner A, Hamann T, Schlüter K, Lucius R, Roider J. Retinal pigment epithelium cells alter the pro-inflammatory response of retinal microglia to TLR-3 stimulation. Acta Ophthalmol [Internet]. 2014;92(8):e621-9. https://doi.org/10.1111/ aos. 12472 . pubmed/24930695.

16. Patel AK, Hackam AS. Toll-like receptor 3 (TLR3) protects retinal pigmented epithelium (RPE) cells from oxidative stress through a STAT3dependent mechanism. Mol Immunol [Internet]. 2013;54(2):122-31. https://doi.org/10.1016/j. molimm.2012.11.005. https://www.ncbi.nlm.nih. gov/pubmed/23267850.

17. Patel AK, Hackam AS. A novel protective role for the innate immunity Toll-Like Receptor 3 (TLR3) in the retina via Stat3. Mol Cell Neurosci [Internet]. 2014;63:38-48. https://doi.org/10.1016/j. mcn.2014.09.004. https://www.ncbi.nlm.nih.gov/ pubmed/25264029.

18. Lai S, Fishman EK, Lai H, Pannu H, Detrick B. Serum IL-6 levels are associated with significant coronary stenosis in cardiovascularly asymptomatic inner-city black adults in the US. Inflamm Res [Internet]. 2009;58(1):15-21. https://doi.org/10.1007/ s00011-008-8150-2. https://www.ncbi.nlm.nih.gov/ pubmed?holding=jhumlib_fft_ndi\&otool=jhumlib\&t erm=Lai+S+Inflamm+Res+2009+58\%3A15-21. 
19. Nagineni CN, Detrick B, Hooks JJ. Toxoplasma gondii infection induces gene expression and secretion of interleukin 1 (IL-1), IL-6, granulocyte-macrophage colony-stimulating factor, and intercellular adhesion molecule 1 by human retinal pigment epithelial cells. Infect Immun [Internet]. 2000;68(1):407-10. https:// doi.org/10.1128/IAI.68.1.407-410.2000. http://iai. asm.org/content/68/1/407.short.

20. Nagineni CN, Cherukuri KS, Kutty V, Detrick B, Hooks JJ. Interferon-gamma differentially regulates TGF-beta1 and TGF-beta2 expression in human retinal pigment epithelial cells through JAK-STAT pathway. J Cell Physiol [Internet]. 2007;210(1):192-200. https://www.ncbi.nlm.nih. gov/pubmed/17013806.

21. Hirano T. Interleukin 6 in autoimmune and inflammatory diseases: a personal memoir. Proc Jpn Acad Ser B Phys Biol Sci [Internet]. 2010;86(7):717-30. https:// www.ncbi.nlm.nih.gov/pubmed/20689230.

22. Detrick B, Gangapuutra S, Palsgrove DN, Heaney CD, Hooks JJ, Sen HN. Elevated serum levels of IL-6 and CXCL9 in autoimmune retinopathy (AIR) patients. J Neuroimmunol. 2018;316:74-9. https:// doi.org/10.1016/j.jneuroim.2017.12.014.

23. Stansky E, Biancotto A, Dagur PK, Gangaputra S, Chaigne-Delalande B, Nussenblatt R, et al. B cell anomalies in autoimmune retinopathy (AIR). Invest Ophthalmol Vis Sci [Internet]. 2017;58(9):3600-7. https://doi.org/10.1167/iovs.17-21704. https://www. ncbi.nlm.nih.gov/labs/articles/28715846.

24. Griffith JW, Sokol CL, Luster AD. Chemokines and chemokine receptors: positioning cells for host defense and immunity. Annu Rev Immunol [Internet]. 2014;32:659-702. https://doi.org/10.1146/annurevimmunol-032713-120145. https://www.ncbi.nlm.nih. gov/pubmed/24655300.

25. Chan CC, Ross RJ, Shen D, Ding X, Majumdar Z, Bojanowski CM, et al. Ccl2/Cx3cr1-Deficient mice: an animal model for age-related macular degeneration. Ophthalmic Res [Internet]. 2008;40(34):124-8. https://www.karger.com/Article/ Abstract/119862.

26. Detrick B, Lee MT, Chin MS, Hooper LC, Chan CC, Hooks JJ. Experimental coronavirus retinopathy (ECOR): retinal degeneration susceptible mice have an augmented interferon and chemokine (CXCL9, CXCL10) response early after virus infection. J Neuroimmunol [Internet]. 2008;193(1-2):28-37. https://doi.org/10.1016/j.jneuroim.2007.09.032. https://www.ncbi.nlm.nih.gov/pmc/articles/ PMC2562577.

27. Nawaz MI, Van Raemdonck K, Mohammad G, Kangave D, Van Damme J, Abu El-Asrar AM, et al. Autocrine CCL2, CXCL4, CXCL9 and CXCL 10 signal in retinal endothelial cells and are enhanced in diabetic retinopathy. Exp Eye Res [Internet]. 2013;109:67-76. https://doi.org/10.1016/j. exer.2013.01.008. https://www.ncbi.nlm.nih.gov/ pubmed/23352833.

28. Rutar M, Natoli R, Chia RX, Valter K, Provis JM. Chemokine-mediated inflammation in the degenerating retina is coordinated by Müller cells, activated microglia, and retinal pigment epithelium. J Neuroinflamm [Internet]. 2015;12:8. https://doi. org/10.1186/s12974-014-0224-1. https://jneuroinflammation.biomedcentral.com/articles/10.1186/ s12974-014-0224-1.

29. Natoli R, Fernando N, Madigan M, Chu-Tan JA, Valter K, Provis J, et al. Microglia-derived IL1 $\beta$ promotes chemokine expression by Müller cells and RPE in focal retinal degeneration. Mol Neurodegener [Internet]. 2017;12:31. https://doi.org/10.1186/ s13024-017-0175-y. https://molecularneurodegeneration.biomedcentral.com/articles/10.1186/ s13024-017-0175-y.

30. Nagineni CN, Kommineni VK, William A, Detrick B, Hooks JJ. Regulation of VEGF expression in human retinal cells by cytokines: implications for the role of inflammation in age-related macular degeneration. J Cell Physiol [Internet]. 2012;227(1):116-26. https:// doi.org/10.1002/jcp.27708. http://onlinelibrary.wiley. com/doi/10.1002/jcp.22708.

31. Nagineni CN, Raju R, Nagineni KK, Kommineni VK, Cherukuri A, Kutty RK, et al. Resveratrol suppresses expression of VEGF by human retinal pigment epithelial cells: potential nutraceutical for age-related macular degeneration. Aging Dis [Internet]. 2014;5(2):88-100. https://doi.org/10.14366/ AD.2014.050088. https://www.ncbi.nlm.nih.gov/ pubmed/24729934.

32. Miller JW. Beyond VEGF-the Weisenfeld lecture. Invest Ophthalmol Vis Sci. 2016;57:6911-8.

33. Fukuoka Y, Strainic M, Medof ME. Differential cytokine expression of human retinal pigment epithelial cells in response to stimulation by C5a. Clin Exp Immunol [Internet]. 2003;131(2):248-53. https://doi. org/10.1046/j.1365-2249.2003.02087.x. https://www. ncbi.nlm.nih.gov/pmc/articles/PMC1808636.

34. Zhu Y, Dai B, Li Y, Peng H. C5a and toll-like receptor 4 crosstalk in retinal pigment epithelial cells. Mol Vis [Internet]. 2015;21:1122-9. https://www.ncbi.nlm. nih.gov/pubmed/26487798. PMC 4588711.

35. Yang P, Tyrrell J, Han I, Jaffe GJ. Expression and modulation of RPE cell membrane complement regulatory proteins. Invest Ophthalmol Vis Sci [Internet]. 2009;50(7):3473-81. https://doi.org/10.1167/ iovs.08-3111. http://iovs.arvojournals.org/article. aspx ?articleid $=2165307$.

36. Hageman GS, Anderson DH, Johnson LV, Hancox LS, et al. A common haplotype in the complement regulatory gene factor $\mathrm{H}(\mathrm{HF} 1 / \mathrm{CFH})$ predisposes individuals to age-related macular degeneration. Proc Natl Acad Sci U S A. 2005;102:7227-32.

37. Lenis TL, Sarfare S, Jiang Z, Lloyd MB, Bok D, Radu RA. Complement modulation in the retinal pigment epithelium rescues photoreceptor degeneration in a mouse model of Stargardt disease. Proc Natl Acad Sci U S A [Internet]. 2017;114(15):3987-92. https://doi. org/10.1073/pnas.1620299114. http://www.pnas.org/ content/114/15/3987.

38. Yang P, Skiba NP, Tewkesbury GM, Treboschi M, Basciu P, Jaffe GJ. Complement-mediated regulation 
of apolipoprotein E in cultured human RPE cells. Invest Ophthalmol Vis Sci [Internet]. 2017;58(7):3073-85. https://doi.org/10.1167/iovs.16-20083. https://www. ncbi.nlm.nih.gov/pubmed/28632844.

39. Detrick B, Rhame J, Wang Y, Nagineni CN, Hooks JJ. Cytomegalovirus replication in human retinal pigment epithelial cells. Altered expression of viral early proteins. Invest Ophthalmol Vis Sci [Internet]. 1996;37(5):814-25. https://www.ncbi.nlm.nih.gov/ pubmed/8603866.

40. Hooks JJ, Chin MS, Srinivasan K, Momma Y, Hooper LC, Nagineni $\mathrm{CN}$, et al. Human cytomegalovirus induced cyclooxygenase-2 in human retinal pigment epithelial cells augments viral replication through a prostaglandin pathway. Microbes Infect [Internet]. 2006;8(8):2236-44. https://www.ncbi.nlm.nih.gov/ pubmed/16782382.

41. Detrick B, Nagineni CN, Grillone LR, Anderson KP, Henry SP, Hooks JJ. Inhibition of human cytomegalovirus replication in a human retinal epithelial cell model by antisense oligonucleotides. Invest Ophthalmol Vis Sci [Internet]. 2001;42(1):163-9. https://www.ncbi.nlm.nih.gov/pubmed/11133862.

42. Rao NA, Saraswathy S, Smith RE. Tuberculous Uveitis: distribution of mycobacterium tuberculosis in retinal pigment epithelium. Arch Ophthalmol [Internet]. 2006;124(12):1777-9. https://doi. org/10.1001/arcchopth.124.12.1777. https://www. ncbi.nlm.nih.gov/pubmed/17159041.

43. Smith JR, Todd S, Ashander LM, Charitou T, Ma $\mathrm{Y}$, Yeh S, et al. Retinal pigment epithelial cells are a potential reservoir for ebola virus in the human eye. Transl Vis Sci Technol [Internet]. 2017;6(4):12. https://doi.org/10.1167/tvst.4.12. https://www.ncbi. nlm.nih.gov/pmc/articles/PMC5512973.

44. Jo DH, Yun JH, Cho CS, Kim JH, Kim JH, Cho $\mathrm{CH}$. Interaction between microglia and retinal pigment epithelial cells determines the integrity of outer blood-retinal barrier in diabetic retinopathy. Glia. 2019;67(2):321-31. https://doi.org/10.1002/ glia.23542.

45. Nebel C, Aslanidis A, Rashid K, Langmann T. Activated microglia trigger inflammasome activation and lysosomal destabilization in human RPE cells. Biochem Biophys Res Commun. 2017;484:681-6.

46. Medawar PB. Immunity to homologous grafted skin; the fate of skin homografts transplanted to the brain, to subcutaneous tissue, and other anterior chamber of the eye. Br J Exp Pathol [Internet]. 1948;29(1):58-69. https://www.ncbi.nlm.nih.gov/pubmed/18865105.

47. Forrester JV, Xu H, Lambe T, Cornall R. Immune privilege or privileged immunity? Mucosal Immunol [Internet]. 2008;1:372-81. https://search.proquest. com/docview $/ 1782984727$ ?pq-origsite $=$ gscholar.

48. Dick AD. Doyne lecture 2016: intraocular health and the many faces of inflammation. Eye (Lond) [Internet]. 2017;31:87-96. https://doi.org/10.1038/ eye.2016.17. https://www.ncbi.nlm.nih.gov/ pubmed/27636226.

49. Morrell CN, Srivastava K, Swaim AM, Lee MT, Chen J, Nagineni CN, et al. Beta interferon suppresses the development of experimental cerebral malaria. Infect Immun [Internet]. 2011;79(4):1750-8. https://doi. org/10.1128/IAI.00810-10. http://iai.asm.org/content/79/4/1750.short.

50. Nagineni CN, Kommineni VK, William A, Hooks JJ, Detrick B. IL-11 expression in retinal and corneal cells is regulated by interferon-gamma. Biochem Biophys Res Commun [Internet]. 2010;391(1):287-92. https:// doi.org/10.1016/jbbrc.2009.11.051. https://www. ncbi.nlm.nih.gov/pubmed/19913506.

51. Gurfein BT, Zhang Y, Lopez CB, Argaw AT, Zameer A, Moran TM, et al. IL-11 regulates autoimmune demyelination. J Immunol [Internet]. 2009;183(7):4229-40. https://doi.org/10.4049/jimmunol.0900622. https:// www.ncbi.nlm.nih.gov/pubmed/19734214.

52. Xu DH, Zhu Z, Wakefield MR, Xiao H, Bai Q, Fang Y. The role of IL-11 in immunity and cancer. Cancer Lett [Internet]. 2016;373(2):156-73. https://doi. org/10.1016/j.canlet.2016.01.004. https://www.ncbi. nlm.nih.gov/pubmed/26826523.

53. Sugita S. Role of ocular pigment epithelial cells in immune privilege. Arch Immunol Ther Exp (Warsz) [Internet]. 2009;57(4):263-8. https://doi.org/10.1007/ s00005-009-0030-0. https://www.ncbi.nlm.nih.gov/ pubmed/19568919.

54. Nagineni CN, Samuel W, Nagineni S, Pardhasaradhi K, Wiggert B, Detrick B, et al. Transforming growth factor-beta indices expression of vascular endothelial growth factor in human retinal pigment epithelial cells: involvement in mitogen-activated protein kinases. J Cell Physiol [Internet]. 2003;197:453-62. https://doi.org/10.1002/jcp.10378. http://onlinelibrary.wiley.com/doi/10.1002/jcp.10378/full.

55. Nagineni CN, Kutty V, Detrick B, Hooks JJ. Expression of PDGF and their receptors in human retinal pigment epithelial cells and fibroblasts: regulation by TGFbeta. J Cell Physiol [Internet]. 2005;203(1):35-43. https://www.ncbi.nlm.nih.gov/pubmed/15368539.

56. Roche PA, Furuta K. The ins and outs of MHC Class II-mediated antigen processing and presentation. Nat Rev Immunol. 2015;15:203-16.

57. Detrick B, Rodrigues M, Chan CC, Tso MO, Hooks JJ. Expression of HLA-DR antigen on retinal pigment epithelial cells in retinitis pigmentosa. Am J Ophthalmol [Internet]. 1986;101(5):584-90. https:// www.ncbi.nlm.nih.gov/pubmed/3518466.

58. Chan CC, Detrick B, Nussenblatt RB, Palestine AG, Fujikawa LS, Hooks JJ. HLA-DR antigens on retinal pigment epithelial cells from patients with uveitis. Arch Ophthalmol [Internet]. 1986;104(5):725-9. https://www.ncbi.nlm.nih.gov/pubmed/3518683.

59. Hooks JJ, Chan CC, Detrick B. Identification of the lymphokines, interferon-gamma and interleukin-2 in inflammatory eye diseases. Invest Ophthalmol Vis Sci [Internet]. 1988;29(9):1444-51. https://www.ncbi. nlm.nih.gov/pubmed/3138201.

60. Percopo CM, Hooks JJ, Shinohara T, Caspi R, Detrick B. Cytokine-mediated activation of a neuronal retinal resident cell provokes antigen presentation. J Immunol [Internet]. 1990;145(12):4101-7. https:// www.ncbi.nlm.nih.gov/pubmed/2147935. 
61. Hamel CP, Detrick B, Hooks JJ. Evaluation of Ia expression in rat ocular tissues following inoculation with interferon-gamma. Exp Eye Res [Internet]. 1990;50(2):173-82. https://www.ncbi.nlm.nih.gov/ pubmed/2107092.

62. Caspi RR. Understanding autoimmunity in the eye: from animal models to novel therapies. Discov Med [Internet]. 2014;17(93):155-62. https://www.ncbi. nlm.nih.gov/pmc/articles/PMC4573559.

63. Wetzig R, Hooks JJ, Percopo CM, Nussenblatt R, Chan CC, Detrick B. Anti-Ia antibody diminishes ocular inflammation in experimental autoimmune uveitis. Curr Eye Res [Internet]. 1988;7(8):809-18. https://www.ncbi.nlm.nih.gov/pubmed/3263258.

64. Robbins SG, Hamel CP, Detrick B, Hooks JJ. Murine coronavirus induces an acute and long-lasting disease of the retina. Lab Invest [Internet]. 1990;62(4):41726. https://www.ncbi.nlm.nih.gov/pubmed/2159082.

65. Robbins SC, Detrick B, Hooks JJ. Ocular tropisms of murine coronavirus (strain JHM) after inoculation by various routes. Invest Ophthalmol Vis Sci [Internet]. 1991;32(6):1883-93. https://www.ncbi.nlm.nih.gov/ pubmed/1851734.

66. Hooks JH, Percopo C, Wang Y, Detrick B. Retina and retinal pigment epithelial cell autoantibodies are produced during murine coronavirus retinopathy. J Immunol [Internet]. 1993;151(6):3381-9. https:// www.ncbi.nlm.nih.gov/pubmed/8397257.

67. Robbins SC, Wiggert B, Kutty G, Chader GJ, Detrick B, Hooks JJ. Redistribution and reduction of interphotoreceptor retinoid-binding protein during ocular coronavirus infection. Invest Ophthalmol Vis Sci [Internet]. 1992;33(1):60-7. https://www.ncbi.nlm. nih.gov/pubmed/1309730.

68. Vinores SA, Wang Y, Vinores MA, Derevjanik NL, Shi A, Klein DA, et al. Blood-retinal barrier breakdown in experimental coronavirus retinopathy: association with viral antigen, inflammation, and VEGF in sensitive and resistant strains. J Neuroimmunol [Internet]. 2001;119(2):175-82. https://www.ncbi. nlm.nih.gov/pubmed/11585619.

69. Komurasaki Y, Nagineni CN, Wang Y, Hooks JJ. Virus RNA persists within the retina in coronavirus-induced retinopathy. Virology [Internet]. 1996;222(2):44650. https://doi.org/10.1006/viro.1996.0442. http:// www.sciencedirect.com/science/article/pii/ S0042682296904420.

70. Wang Y, Detrick B, Hooks JJ. Coronavirus (JHM) replication within the retina: analysis of cell tropism in mouse retinal cell cultures. Virology [Internet]. 1993;193(1):124-37. https://www.ncbi.nlm.nih.gov/ pubmed/8382393.

71. Hooks JJ, Wang Y, Detrick B. The critical role of IFN-gamma in experimental coronavirus retinopathy. Invest Ophthalmol Vis Sci [Internet]. 2003;44(8):3402-8. https://www.ncbi.nlm.nih.gov/ pubmed/12882788.

72. Wang Y, Burnier M, Detrick B, Hooks JJ. Genetic predisposition to coronavirus-induced retinal disease. Invest Ophthalmol Vis Sci [Internet]. 1996;37(1):250_ 4. https://www.ncbi.nlm.nih.gov/pubmed/8550331.

73. Hooks JJ, Detrick B, Percopo C, Hamel C, Siraganian RP. Development and characterization of monoclonal antibodies directed against the retinal pigment epithelial cell. Invest Ophthalmol Vis Sci [Internet]. 1989;30(10):2106-13. https://www.ncbi.nlm.nih.gov/ pubmed/2477341.

74. Hamel CP, Tsilou E, Pfeffer BA, Hooks JJ, Detrick $\mathrm{B}$, Redmond TM. Molecular cloning and expression of RPE65, a novel retinal pigment epithelium-specific microsomal protein that is post-transcriptionally regulated in vitro. J Biol Chem [Internet]. 1993;268(21):15751-7. https://www.ncbi.nlm.nih. gov/pubmed/8340400.

75. Morimura H, Fishman GA, Grover SA, Fulton AB, Berson EL, Dryja TP. Mutations in the RPE65 gene in patients with autosomal recessive retinitis pigmentosa or Leber congenital amaurosis. Proc Natl Acad Sci U S A [Internet]. 1998;95(6):3088-93. https://www. ncbi.nlm.nih.gov/pubmed/9501220.

76. Bainbridge JW, Smith AJ, Barker SS, Robbie S, Henderson R, Balaggan K, et al. Effect of gene therapy on visual function in Leber's congenital amaurosis. N Engl J Med [Internet]. 2008;358:2231-9. https://doi. org/10.1056/NEJMoa0802268. http://www.nejm.org/ doiI/full/10.1056/NEJMoa0802268\#t=article. 